\title{
CEsifo \\ WORKING

The European Social Welfare Function Shaped on a Difference Principle: A Normative Rawlsian Approach in Favour of Fiscal Union

Klaudijo Klaser 


\section{Impressum:}

CESifo Working Papers

ISSN 2364-1428 (electronic version)

Publisher and distributor: Munich Society for the Promotion of Economic Research - CESifo $\mathrm{GmbH}$

The international platform of Ludwigs-Maximilians University's Center for Economic Studies and the ifo Institute

Poschingerstr. 5, 81679 Munich, Germany

Telephone +49 (o)89 2180-2740, Telefax +49 (o)89 2180-17845, email office@cesifo.de

Editors: Clemens Fuest, Oliver Falck, Jasmin Gröschl

www.cesifo-group.org/wp

An electronic version of the paper may be downloaded

- from the SSRN website: $\quad$ www.SSRN.com

- from the RePEc website: $\quad$ www.RePEc.org

- from the CESifo website: www.CESifo-group.org/wp 


\title{
The European Social Welfare Function Shaped on a Difference Principle: A Normative Rawlsian Approach in Favour of Fiscal Union
}

\begin{abstract}
Why might the European member states seek for Fiscal Union? Coordination, macro-stability purposes and provision of (European) public goods are certainly goals of paramount importance for the implementation of Fiscal Union at European level. However, there is an equally important component of moral-normative nature embodied in the constitution of any fiscal system: reallocation of resources. The core of the paper is the idea that Rawls' social contract theory can provide some insights about the implementation of European Fiscal Union in the reallocative perspective. The reasoning put forward in the paper shows how the current European framework can be essentially considered an appropriate object of Rawls' theory of domestic justice since the European Union holds those two descriptive elements which are sufficient and necessary to raise redistributive issues, to apply Rawls' pure procedural justice and then to derive a difference principle at European level: a) the mutually advantageous cooperation among its members and $b$ ) a set of formal institutions which constitute a basic structure. The European difference principle prescribes to redistribute resources in order to maximize the expectations of the most disadvantaged European citizen(s). A corollary of this conclusion is that the actual redistribution according to similar scheme is achievable by means of Fiscal Union at European level.
\end{abstract}

JEL-Codes: D300, E620, F550.

Keywords: difference principle, European integration, European Union, Fiscal Union, John Rawls.

\author{
Klaudijo Klaser \\ Doctoral School of Social Sciences \\ University of Trento \\ Via Verdi 26 \\ Trento / Italy \\ klaudijo.klaser@unitn.it
}

I am grateful to Fondazione Cassa Rurale di Trento which provided a consistent grant for the development of the paper. Different versions of the paper were presented at various conferences and workshops (Cesifo, INET, Fondazione Istituto Cattaneo and SISP. 


\section{Introduction}

The European Union is a compound of nation-states characterized by a particular institutional asymmetry: as pointed out with different emphasis by Ferrera (2009), Martinsen (2013) and Scharpf (2002) while the main economic issues are directly or indirectly addressed at community level, social welfare policies remain an exclusive prerogative of eache the single member states. That implies that each European member country has its own optimal social policy to respond (with potential negative spillover effects, see Andreozzi et al. 2017) to the same common economic framework outlined at European level ${ }^{1}$. That contributes to generate a fragmented European social structure, because significant inequalities and heterogeneous re-distributive effects emerge between and within the European countries (Avram et al. 2014, Beckfield 2006, Immervoll et al. 2006, Fredriksen 2012). The financial and economic crisis of the last decade contributed then to accentuate the impact, in terms of inequalities, of this structural asymmetry which prevented a unified and effective response of the European Union institutions to the social needs of its citizens during the crisis. Ferrera (2014) and Martinsen et al. (2014) highlight this kind of hindrance and the consequent lack of responsiveness during the crises.

Given this current two-levels design there are three possible options for the future development of the European Union. The baseline alternative is to keep the status quo: for the European Union it is certainly possible to continue to be an institutional chimera (a condition where many national welfare systems coexist within a uniform European economic framework) to the extent that (economic) gains somehow compensate (social) disadvantages ${ }^{2}$. The second option relies on a never old-fashioned paradigm, that is to re-establish the symmetry between the economic and social sphere moving back to the original state of affairs. In this last perspective the European countries are supposed to take back those (economic) decision-making powers they have gradually ceased in favour of the European Union, and in the light of the recent Brexit case this option is not an abstract case study for professional thinkers anymore. The third and the last hypothesis is suggested by Maduro (2000), Sangiovanni (2013) and Vandenbroucke (2013). It looks at the opposite direction and embraces the idea to fill up the institutional gap shifting in a certain degree the European Union from being a mere economic infrastructure towards a reality more careful to the social dimension of its citizens. A natural consequence of this perspective is then the necessity to endow the European Union with some concrete social welfare tools and with specific dedicated resources ${ }^{3}$.

The reasoning suggested in the paper shows how the constitutive elements which currently characterize the European Union substantially imply the third option. The conclusion that the

1 A significant practical example is the interest rate: 19 structurally different European countries face the same interest rate adopted by the European Central Bank.

2 Or said otherwise, up to the point where the trade-off between economic efficiency and social equality at European level keeps unbalanced in favour of the former.

3 This is not to say that the European Union totally lacks of any social view. The European Union currently has some (thin) social traits, as shown by many authors (Buchanan 1996, p 253, Dluhosch 1996, pp. 338-339, Kölling 2015, p. 86, Streit et al. 1995, p. 319 and p. 338, Vaubel 1996, p. 317). However its redistributive policy (which exists, even if limited) so far has been mostly driven by reasons of pure economic compensation. Thus the adopted criteria for the limited redistribution of the limited resources mostly depended on bargaining powers of the single involved countries rather than on some explicit social purposes (Maduro 2000). 
European Union, given its current configuration, should move towards a stronger social integration, reducing its inner institutional asymmetry and then the underlying inequalities, is reached through the adoption of a very peculiar perspective ${ }^{4}$ : the Rawlsian social contract theory and its impartial mechanism of the veil of ignorance (Rawls 1999). The reasoning which follows can be essentially split into two main blocks:

- the first step consists in identifying, within the European Union, those elements which are sufficient and necessary to apply Rawls' social contract theory. In particular, I will show the existence, from an empirical point of view, of two fundamental elements at European level: a) a mutually advantageous cooperation among its members, b) a set of formal institutions which constitute a basic structure.

- it is then necessary to linger the attention on the direct consequences deriving from the application of Rawls' social contract theory to the European Union, that is the European difference principle. Furthermore I will introduce a corollary of the major conclusion: if European citizens want to handle their common institutions with the aim to adopt a European redistributive social policy which reflects the difference principle scheme, the European member states might implement Fiscal Union at European level ${ }^{5}$.

At this stage of the reasoning the locution "Fiscal Union" might be misleading. Depending on the context in which is adopted it can reference to different meanings, suggest multiple aims, usually derived from the broader field of public finance (Musgrave et al. 1989), and more generally it can be implemented in different degrees and can be characterized by different specific elements (Fuest et al. 2012). For instance (European) Fiscal Union might be realized with the unique aim to provide some specific (European) public goods, like a common military defense. Fiscal Union can suggest then a concept of shared and binding rules concerning the tax policy within a set of defined economic and political entities. Another possible interpretation implies a shared pool of resources aimed to face some systemic risks which can be managed better together than from an isolated point of view.

All these representations are certainly relevant when they are associated to the European context. However, to avoid misunderstandings, it is important to specify from the beginning which exact meaning is given to the expression "Fiscal Union" throughout the next pages: hereafter with the words "Fiscal Union" it will be meant a European system which can pool together into a common budget the resources necessary to pursue and to implement a Rawlsian redistributive social policy within the European Union. Neither economic factors (specific tax policies, exact amount of the common budget, etc.) nor political equilibria (legitimization, bargaining rules, decision-making powers, etc.) will be taken in consideration if not in an accessory way.

The next Sections are then organized as follows. Section 1 briefly introduces the methodological issue of approaching the European Union integration from the perspective of John Rawls' social contract theory. Section 2 is descriptive and focuses the attention on those European

4 Different perspectives and methodologies might be adopted to derive the principles for the European social justice (Dunaiski 2013, Rawls et al. 2003, Sangiovanni 2013, Scharpf 2002, Van Parijs 2012, Viehoff 2016).

5 Within the context of the present paper Fiscal Union at European level is not to be interpreted as a direct outcome of the analysis of the European Union in a Rawlsian perspective, but simply as a corollary. The straightforward outcome of the analysis is the European difference principle, which embodies the purpose of social integration; Fiscal Union is only one of the possible means to achieve that purpose. 
empirical elements which allow the adoption of Rawls' social contract theory. Section 3 provides the main outcome of applying Rawls' social contract theory to the European Union, that is the European difference principle. Section 4 lingers on a corollary of the European difference principle, that is European Fiscal Union. The conclusions summarize the main ideas, provide some final remarks and address the future research.

\section{John Rawls' social contract theory and the European Union: a methodological issue}

John Rawls conceived an impartial procedure to identify those principles (norms) which can guarantee a fair institutional arrangement at national level (Rawls 1999) and at international level (Rawls 2001). In developing his theories Rawls renovated the social contract tradition, proposing a contractual procedure to establish the main principles which are supposed to lead human society and its institutions. Within the Rawlsian theory the impartiality in the choice of the norms (principles) is achieved through the veil of ignorance, a tool which excludes the access to any particular information to those parties that are involved in the agreement. Furthermore, although the whole decision-making process and the agreement (which take place in the so called original position) are conceived by Rawls as purely hypothetical, their ideal derivation has precise concrete effects.

Indeed, even tough the veil of ignorance is supposed to be only a mental experiment, the agreed principles of justice (norms to shape institutions and chosen through the maximin criterion) have prescriptive effects in the real world after the veil (again, hypothetically) is dropped. In particular, at national level (Rawls 1999) the first principle establishes the implementation for single individuals of a scheme of liberties as broad as possible and compatible with the liberties of everybody else; the second principle of justice, relabelled by Rawls himself as "difference principle", requires to redistribute those resources achieved by means of social and economic cooperation (which involves the contractual parties) in order to maximize the expectations of the (group of) individual(s) most disadvantaged. As far as the international is concerned Rawls (2001) lists eight distinct principles which are supposed to regulate the relationships between countries in a fair institutional framework. In short, according to Rawls and his social contract theory, the main institutions of a modern society must be arranged to fulfill as much as possible the prescriptions of the principles of justice impartially chosen in the original position behind the veil of ignorance.

Given this theoretical framework, when we move a step aside and we try to approach the European Union in the light of Rawls' social contract theories we bump into a quite weird conclusion: despite having also an international perspective, Rawls appears to be eurosceptic. Indeed, it seems to be natural to interpret some of his explicit references to the European Union as symptoms of a more or less marked euroscepticism: "one question the Europeans should ask themselves, if I may hazard a suggestion, is how far-reaching they want their union to be" (Rawls et al. 2003 p. 9); "the large open market including all of Europe is aim of the large banks and the capitalist business class whose main goal is simply larger profit" (Rawls et al. 2003 p. 9).

Thus, basing their analysis on the quoted claims, the previous (rare) attempts to interpret the European Union in the light of Rawls' thought directly or indirectly provided an unfavourable exegesis of the European project. Kamminga (2014) insists on rejecting the idea to interpret the European Union from any Rawlsian perspective because, according to him, the European Union is incomplete and lacks some fundamental elements to apply Rawls' theories. Barcelos et al. (2008) 
assume a different perspective. In their opinion the European Union is an unidentified political object, characterized by a mix of national and international elements. Therefore we cannot approach the European Union with the standard Rawlsian theories, because neither Rawls' international theory nor his domestic justice squarely fit a hybrid and continuously evolving institution like the European Union. Thus they conclude that "given this hybrid nature of the Union, the description of its values by analogy with the domestic society [...] is, therefore, unacceptable [...] This same hybridism, in the same way, excludes the possibility of conforming the EU to the [...] model defended in The Law of Peoples" (Barcelos et al. 2008, p. 9). Using a numerical example Morgan (2008) claims the implicit contradictions of a European redistributive principle with the national redistributive policies. That consideration apparently prevented Rawls from endorsing the European project, because he was aware of those possible contradictions.

Thus, if we rely on the eurosceptic interpretation it becomes immediate to infer that the European countries should avoid adopting any common fiscal system for redistributive purposes ${ }^{6}$, since, first of all according to John Rawls himself, when we deal with any remarkable project of European integration cons prevail on pros. However, the conclusion about John Rawls' euroscepticism has to be considered too hasty for one important reason: despite conceiving both, a national and an international theory, in his writings Rawls only marginally took into consideration the European framework. In other words the European Union is not structurally contextualized within Rawls' works. He neither conceived a specific European social contract theory nor he explicitly included the European Union as a formal object of any of his writings. This theoretical emptiness, more than his few explicit (non positive) references concerning the European Union, paved the way to the eurosceptic interpretation. Yet the mentioned lack of a theoretical framework cannot justify the monotonically negative interpretations of the European Union in the perspective of John Rawls' thought and theories. Of course there are some difficulties in the interpretation task, but it is also possible to infer some positive results from applying the Rawlsian social contract theory to the European Union. In the following Sections I show how it is possible to approach the European context through Rawls' domestic (national) theory (Rawls 1999). This approach leads to the conclusion that the European Union should move towards greater social integration.

\section{The European Union: economic cooperation and basic structure}

According to the structure given by John Rawls to his domestic theory (Rawls 1999), to apply the related categories and to draw the related conclusions, it is necessary and sufficient to rely on two elements: a scheme of mutually advantageous cooperation ${ }^{7}$ and an institutional basic structure ${ }^{8}$.

6 Similar conclusion appears even more true if we consider that Rawls himself explicitly refused to derive any kind of international redistributive principle (Rawls 1993, 2001).

7 "Although a society is a cooperative venture for mutual advantage, it is typically marked by a conflict as well as by an identity of interests. There is an identity of interests since social cooperation makes possible a better life for all than any would have if each were to live solely by his own efforts. There is a conflict of interests since persons are not indifferent as to how the greater benefits produced by their collaboration are distributed" (Rawls 1999, p. 4).

8 The basic structure refers to "the way in which the major social institutions fit together into one system, and how they assign fundamental rights and duties and shape the division of advantages that arises through social cooperation" (Rawls 1977, p. 159). 
Without those two components it is not possible to apply the domestic theory ${ }^{9}$. Thus, applying Rawls' domestic categories to the European Union requires to verify, from an empirical point of view, whether or not the European Union holds the two mentioned elements.

Before moving in that direction it is useful to highlight how it is beyond the aims of the present analysis to enter the debate on what exactly the European Union is (a federation, a confederation, an association of compound states, see Buchanan 1996 and Blankart 2007), how the powers within the Union are or should be balanced (Vaubel 1996 and Vaubel 1997), or how its institutions are or should be legitimized. The existence of certain structural elements is independent from how we technically prefer defining the European Union. The main intent of the next paragraphs is simply descriptive, that is they aim to provide the empirical evidence of those elements ${ }^{10}$ which allow to apply the Rawlsian domestic justice and its categories at European level.

As for the economic and social interaction meant as a cooperative venture for the mutual advantage (which generates benefits and conflicts), it is not difficult to acknowledge similar scheme of cooperation within the European Union. Following Beitz's insight about the effects of globalization (Beitz 1999, pp. 143-153) it can be immediately noticeed how the "international economic interdependence constitutes a scheme of social cooperation" (Beitz 1999, p. 154) as exactly as meant by Rawls for a simple national (closed) system. As regards the specific case of the European Union and from the point of view of constitutional economics ${ }^{11}$ Beitz's insight is even more convincing: the economic integration process which had begun with the Treaty of Rome (1957, Title I and Title III) gave birth to a formal scheme of mutual cooperation which can be easily interpreted in the Rawlsian sense. The European Economic Community (Single Market) with its free circulation of goods, persons, services and capitals constitutes a clear example of social and economic scheme of mutually advantageous interdependence. Of course, as suggested by Beitz, similar kind of cooperation exists even at a broader international level, but that is not relevant with regards the current analysis.

As far as the benefits generated by the European economic cooperation are concerned, although the economic theory does not agree about the permanent or temporary effects of a market integration (Badinger 2005), the positive economic outcomes of a market enlargement are broadly recognized since Adam Smith's Wealth of Nations (Smith 19994), where he grasped the positive implications of the size of a market on the division of labour, and then on the productivity through specialization. The literature is not unanimous about the precise quantitative effects derived from the European economic integration (Badinger et al. 2011) and its determinants are not always

9 I deliberately avoid entering the debate on which further elements are considered essential to make redistributive concerns emerge and then to justify principles of redistributive justice and redistributive institutions, like for example a certain degree of coercion (Nagel 2005 or Blake 2001). Since it is still an open debate (Blake 2016, Sangiovanni 2016 and Valentini 2011) here it is preferable to stick to the basic Rawlsian framework as strictly as possible.

10 Those two (Rawlsian) elements are empirical assumptions it is possible to disagree about, as clearly explained by Blake (2012, p. 122-126).

11 According to Buchanan the "constitutional economics examines the choice of constraints as opposed to the choice within constraints" (1991, pp. 134-135): Furthermore it is important to remark how the same author (Buchanan 1991, p. 141) explicitly claims how the Rawlsian distributive problem is an object of study of the constitutional economics. 
completely clear (Campos et al. 2014 and König et al. 2012). Nevertheless many studies agree on how the European countries have benefited from the institution of the common market institution (Badinger et al. 2011, even though the authors highlight how most of the studies are more ex-ante predictive analysis rather than ex-post quantitative investigations, p. 308).

Despite different methodologies and a "quantitative disagreement", the following remarks are sufficient to highlight some of the benefits gained from the European common market (economic cooperation). Over the period 1950-2000 the "European integration has significantly contributed to the post-war growth performance of the current EU member states" such that "GDP per capita of the EU would be approximately one-fifth lower today if no integration had taken place" (Badinger 2005, pp. 73-74). "EU membership has had a positive and asymmetric effect on long-term economic growth" on the EU-15 member states (Crespo Cuaresma et al. 2008, p. 652). In addition "there seems to be strong evidence on positive pay-offs from EU membership, despite considerable heterogeneity across countries" and in a prudent counterfactual evaluation "incomes would have been around 12 per cent lower today if European Integration had not happened" (Campos et al. 2014, p. 25 and p. 21). What should be clear from these empirical instances and from the framework explained so far is that the overlap between the Rawlsian concept of a venture for the mutual advantage and the European Economic Community (Single Market) is straightforward: the Treaty on the common market formally defined the mutually advantageous venture ${ }^{12}$ meant in a Rawlsian sense. It is then an empirical task to measure the exact economic surplus gained from the free European market integration.

As for the second element considered essential in order to apply Rawls' theory of domestic justice, it is not difficult to identify within the European Union a set of common institutions and agencies which, in the logic of the present writing, can be interpreted as a European basic structure. The Treaty of Lisbon (Article 13) formally lists seven common institutions ${ }^{13}$ whose tasks are to provide political direction, to manage the Union and to integrate the conflicting interests (Peterson et al. 2012): elective European Parliament, European Council, Council (of Ministers), European Commission, Court of Justice of the European Union, European Central Bank and Court of Auditors. These seven institutions are then surrounded by hundreds of agencies and organizations ${ }^{14}$ (Mathieu 2016) which, performing sometimes at the limits of their formal powers (Chamon 2016), operate in accordance with the guidelines of the main institutions mentioned above. These agencies, together with the main institutions, affect individuals' prospects of live in different spheres, ranging from ensuring an area of freedom, security and justice (for example Frontex, the European Border and Cosat Guard Agency) to supervising financial systems (for instance EBA, European Banking Authority), from providing defense (EDA, European Defence Agency) to supporting EU business and innovation in the digital, energy, innovation and transport sectors, from directly fostering citizens' well-being, like for example through the European Centre for Disease Prevention and

12 Of course it is not necessary a formal treaty for the existence of mutually advantageous economic and social relationships. Nevertheless a formal treaty is an additional element which strengthens the Rawlsian domestic interpretation of the European Union.

13 It is not among the aims of the present analysis to provide a detailed description of the main European institutions, nor, as stated in advance, enter in a debate regarding the equilibria between them or their legitimization.

14 For a complete map of the agencies see the official website https://euagencies.eu/. 
Control (ECDC) to helping the developing countries to exploit the potential of their human capital through the European Training Foundation (ETF).

In short, the main European institutions and all the agencies which surround them constitute a dense institutional network which shapes a European basic structure. However, some remarks are due about the European institutional network interpreted as a Rawlsian basic structure. First of all in a Rawlsian perspective the quantity of institutions on the European territory (probably at global level we can count many more international institutions) is not relevant. Instead, what matters is the substantive quality of those institutions: they are supposed to be capable of affecing, either by themselves or in conjunction, the distribution of duties and rights, that is to affect people's prospects of life. In this perspective the European institutions and their derivatives can effectively and concretely "distribute fundamental rights and duties and determine the division of advantages from social cooperation" (Rawls 1999, p. 6). They can deeply affect Europeans' plans of life. A similar concept can be reinforced with some concrete examples: a sentence of the Court of Justice of the European Union can directly and radically affect the prospect of life of any (group of) European citizen(s). The same reasoning may be extended to a ban on pesticides voted by the European Parliament, or to the interest rate set by the European Central Bank. Moreover, it should be pointed out that a basic structure is not a binomial (zero or one) reality, which eother does not exist at all or which exists in its full configuration. A basic structure is instead an object which spans on a sort of continuous spectrum: in this perspective it should be indisputable how the European basic structure is closer to one (full representation) than to zero even if it might be considered incomplete in a certain degree (compared to those national ones). Furthermore, it is relevant to underline how the European basic structure is not constituted by mere second-side institutions which have the only aim of fostering the national ones (Blake 2013, pp. 108-132). The European institutions act with their own tools and with their own goals. Lastly, it is important to highlight how another international basic structure as (qualitatively) complete as the European one cannot be identified beyond the European boundaries nor at any broader international level.

In conclusion, the European economic cooperation and the European basic structure represent the essential prerequisites to apply Rawls' domestic social contract theory to the European Union. The next Section, focuses on the outcomes of the European social contract in a Rawlsian perspective following a reasoning by analogy: the derivation of the European difference principle as normative redistributive rule at European level and its corollary, that is European Fiscal Union.

\section{The European difference principle}

Given that the European Union holds the essential elements for the application of the Rawlsian domestic theory it is possible to adopt its formal categories of interpretation. Said otherwise, it is now possible to make explicit which principles are conceivable for the European Union as a whole in the perspective of the Rawlsian social contract. For a reasoning by analogy, European individuals behind the veil of ignorance ${ }^{15}$ would substantially agree on the standard (national) principles (Rawls 1999, pp. 52-56) ${ }^{16}$ to shape the European Union. The principles, although formally domestic, they substantially become valid across the European member states, regardless the national borders.

15 See (Rawls 1999, pp. 118-123).

16 "The first principle simply requires that certain sorts of rules, those defining basic liberties, apply to everyone equally and that they allow the most extensive liberty compatible with a like liberty for all" (Rawls 1999, p. 56), 
Indeed, since the Europeans are deprived by the veil of ignorance of any particular information, overall of that specific information concerning the territory where they (might) live in terms of resources, size of the population, boundaries, economic development and so on and so forth (Rawls 1999 pp. 32-33) they would choose exactly the same two principles conceived by Rawls for the standard domestic case (1999, pp. 52-65, pp.130-139 and pp. 153-160) and they would rationally decide to apply them across the European Union considered as a whole.

Thus, the content of the principles chosen behind the European veil of ignorance remains exactly the same as for the typical national "closed system", but the actual range of their application is identified according to the considered basic structure (extension of cooperation), in this case the European Union. The outcome is rigid with regards the essence of the principles (same conditions, same outcome), while the range for their application is tailored on the European territory. Again, the cut-off point (Martin 2006, pp. 227-234 and Martin 2015, p. 749) for the application of the (domestic) principles in a European perspective has to coincide with the European Union as a whole. Indeed, behind the (European) veil there are no rational reasons to decide to apply the principles within the boundaries of the single member countries, and this is particularly true for the difference principle which affects the redistribution of resources. Behind the veil it is irrational to apply the principles within specific countries: in a European perspective any ex-ante (behind the veil) decision which identifies a specific internal boundary or a territorial limit for the application of the principles has to be considered arbitrary and against the maximin reasoning. Thus, the range of validity of the European principles must coincide with the extension of the institutions (cooperation) considered behind the veil.

Focusing now the attention on the redistributive issue, it is possible to claim how behind the veil of ignorance European citizens would agree to arrange the social and economic inequalities to the greatest expected benefit of the least advantaged European individuals ${ }^{17}$, regardless the country or the nationality: that is equivalent to enunciate a European difference principle which operates at individual level ${ }^{18}$ across and beyond the boundaries of the single European member states. A normative analysis of the European redistributive issue in a Rawlsian (domestic) perspective leads to shape the European institutions so that the resources generated by the social and economic cooperation within the Union must be redistributed to favour the least advantaged (in terms of social primary goods ${ }^{19}$ ) Europeans: the difference principle is not "statist" in its assumptions

whereas the second principle, the so called difference principle requires to "maximize the expectations of the least favored position" (Rawls 1999, p. 69).

17 See (Rawls 1999, pp. 69-72).

18 This specification seems to be necessary because we might be tempted to think that, since the actors at the European level are basically nation-states, the rationale should be to redistribute toward the worst-off member state instead of the least advantaged (group of) individuals between states. However, this hypothesis violates the assumptions of the Rawlsian domestic social contract theory (which takes individuals as actors) and generates a clear paradox: if we assume redistribution between member states, in the perspective of a difference principle at European level we should redistribute resources from Greece (higher GDP) to Luxembourg (lower GDP), or from Poland (higher GDP) to Norway (lower GDP), although Luxembourg and Norway are two countries among those with the highest GDP per capita.

19 The social primary goods "are things which it is supposed a rational man wants whatever else he wants" (Rawls 1999 p. 79), and the social primary goods index avoids problems of comparability (Rawls 1999, pp. 78-81). 
anymore (Kuper 2000, pp. 653-654) and it basically becomes transnational (even if derived from the application of a national theory).

To reinforce the reasoning presented so far it is possible to provide an introductory example concerning the working mechanism of the European difference principle. To start, imagine three European countries (Figure 1) which act in isolation and which arrange their inner inequalities in such a way that the least advantaged ${ }^{20}$ in country A reaches an index of social primary goods of 2 points, the worst-off in $\mathrm{B}$ reaches an index of 7 points and the worst-off in country $\mathrm{C}$ an index of 5 points. This is the typical situation conceived by John Rawls, where every country substantially worries about the distribution of its own resources and countries do not consider endorsing any agreement to share or to redistribute their own social primary goods beyond their boundaries. At the same time Figure 1 adds a further hypothesis: if the three countries operate not only as autarkies, but they cooperate together (that is their citizens constitute an international venture for the mutual advantage), they can generate a common surplus (EU) of 10 points, since they would profit from their (international) comparative advantages.

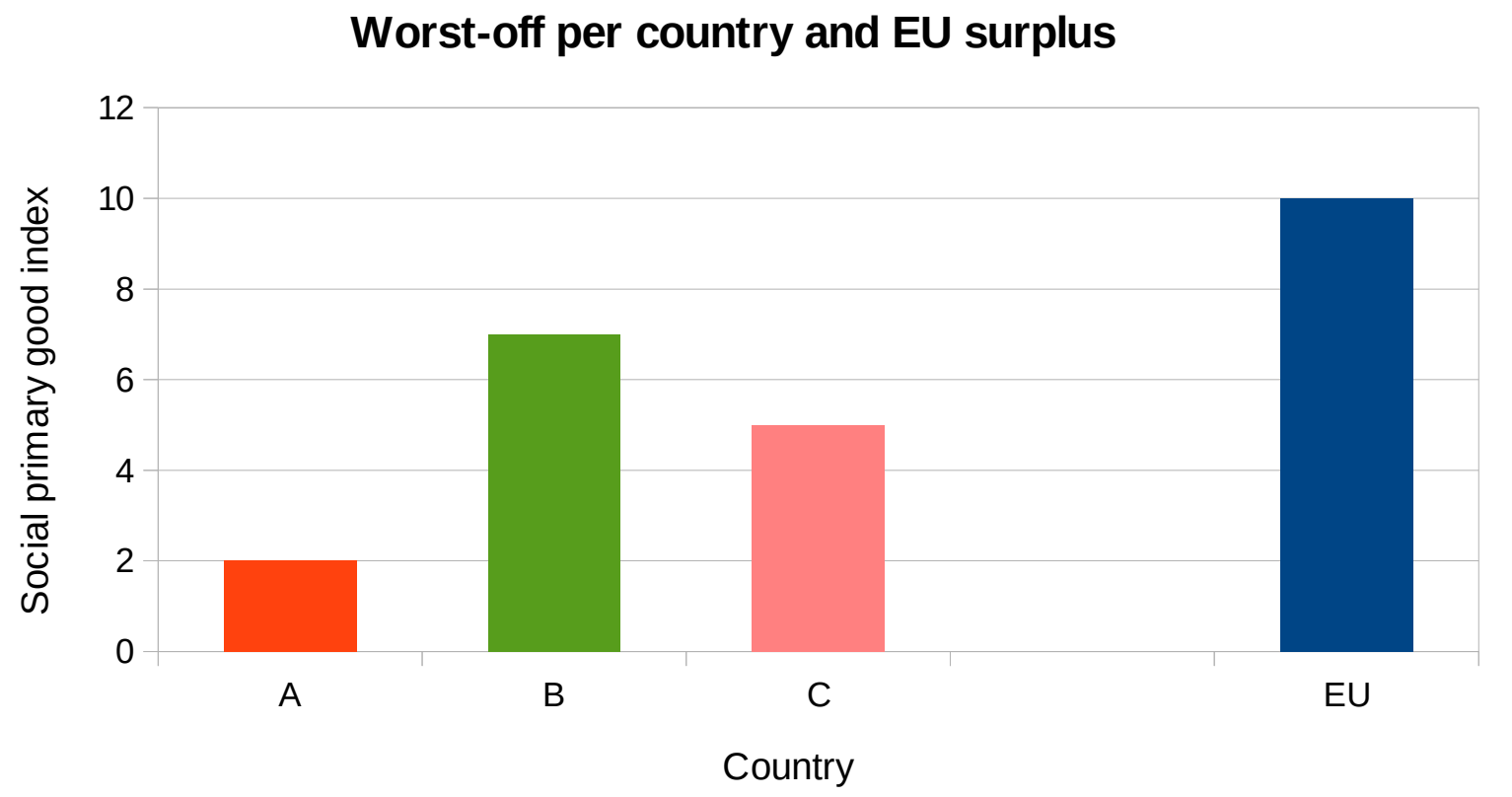

FIGURE 1: Acting in isolation (and according to their domestic difference principle) the three European countries A, B and $\mathrm{C}$ can maximize the expectation of the least advantaged of their own nations as shown by the respective coloured histograms. Should the individuals of the three countries cooperate together they could generate a common surplus, EU.

Furthermore, the existence of a redistributive principle between states may lead to the problem of redefining the Rawlsian bundle of social primary goods [15, pp. 78-81], as very cleverly grasped by Paden [62, pp. 226-227].

20 Of course also those groups of individuals who are better-off should be taken into consideration. However, the reppresentation of those groups in the provided examples would not add anything to the general concept. 
Now imagine a second situation. Individuals in the three European countries engage in a mutually advantageous cooperation and, exploiting their comparative advantages, they generate a surplus at European level. However there is no any clear redistributive scheme, or said otherwise, European citizens do not agree on any redistributive principle which prescribes how to share the surplus EU. It is then plausible to assume how the surplus is arbitrary divided by market forces or by the bargaining powers of the single nations (Figure 2). In this situation, where there is not a formal redistributive principle or where there is not a set of institutions (basic structure) which can concretely redistirbute the common surplus EU, the social primary goods index of the worst-off among the least advantaged (located in country A) is assumed to improve by only 1 point. In this situation the worst-off in country A reaches an index of social primary goods of 3 . The total index increases up to 12 for the least advantaged in country B and up to 9 in country C.

Market division of the EU surplus

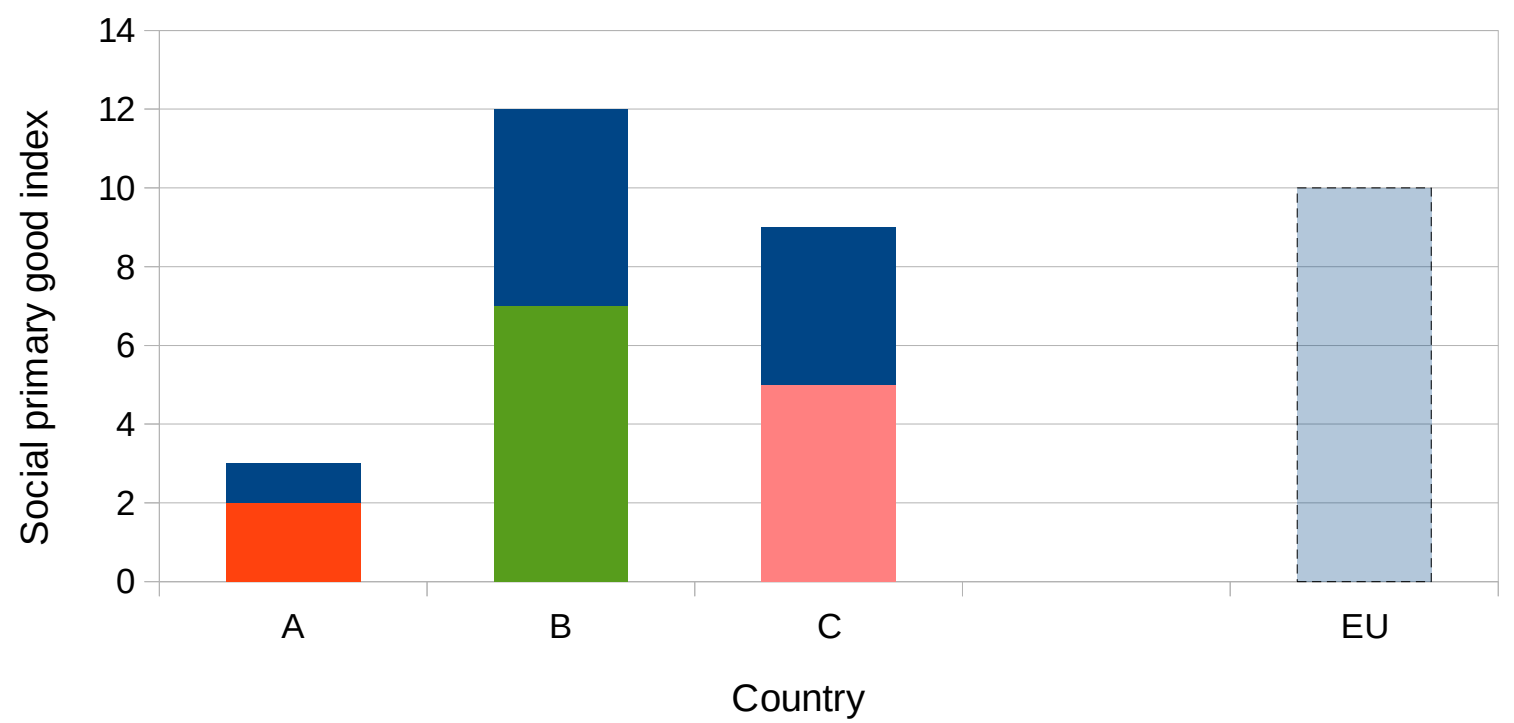

FIGURE 2: Cooperating at European level without reaching an agreement on how to distribute the surplus EU or without having a basic structure leaves the redistribution at the mercy of other forces.

How is the European difference principle supposed to act? The initial situation is the same as in the second example, with the three countries that engage in mutual cooperation. This time however, the European surplus EU is supposed to be redistributed in order to benefit the worst-off between the three countries (considered as a unique set). Figure 3 shows an egalitarian distribution ${ }^{21}$ in line with the European difference principle any worst-ott gets a total of 8 points in terms of social primary goods: the index of the least advantaged is thus maximized. In short, the redistributive scheme proposed in Figure 3 is to be considered as the natural outcome of the European difference principle.

21 The egalitarian distribution is not the only one coherent with the difference principle: unequal distribution are possible as long as they bring the maximum advantage to the worst-off. 


\section{Division of the EU surplus according to the difference principle}

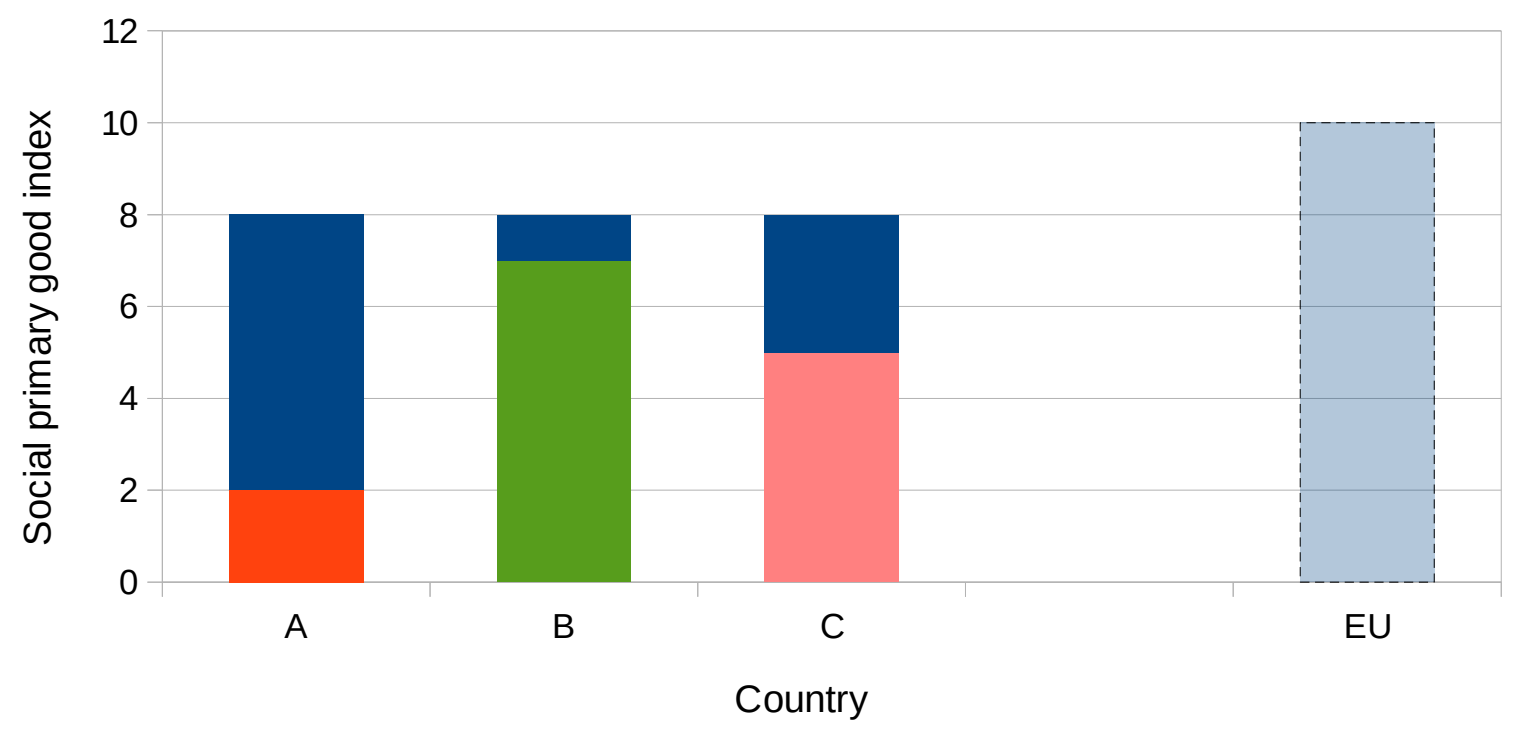

FIGURE 3: Egalitarian distribution of the EU surplus according to the European difference principle, which maximizes the expectations of the worst-off between those who are the least advantaged within the single countries.

\section{European Fiscal Union in a Rawlsian perspective}

Even if we agree with the theoretical analysis provided so far, it remains unclear how the surplus EU should be quantified and how the resources generated by means of the European cooperation should be physically pooled together to be then redistributed. As for the first issue (quantification) the answer seems to be quite straightforward. The estimate of the European surplus is matter for an empirical investigation. Following the studies presented in Section 2 (Badinger 2005, Badinger et al. 2011, Campos et al. 2014 and Crespo Cuaresma et al. 2008) the European surplus is supposed to be calculated as the (counterfactual) difference between the current level of the European economic activity and the (aggregated) hypothetical economic level should the European countries act as pure autarkies (with no transnational cooperation with other European member states).

Even if the empirical estimate of the European surplus is not a theme of the present (theoretical) paper, one remark about it is considered essential: the European difference principle, such as conceived, does not have to substitute the national redistributive mechanisms, because it cannot act on all the available resources within the European Union (both national and common) ${ }^{22}$.

22 Intuitively, applying a European redistributive rule on the total surplus (national ones and European) might erode the social primary goods index of some individuals who are better-off without the common redistributive scheme. Morgan (2008, p. 9) provides a numerical example which highlights such a possibility: applying a unique difference principle between nations might lead to a contradicting situation where the worst-off individual of some particular state is made still more disadvantaged compared to the situation where a difference principle is applied independently within every single country. In other words a "society, or group of such societies, [might] be worse off under a [European] basic structure than in perfect isolation" (Pogge 1988, p. 249). On that issue two further 
Instead, it prescribes to redistribute exclusively that surplus generated by the social and economic cooperation which takes place at European level. In other words, according to the European difference principle redistribution has to be realized only on those resources which are the product of the scheme of the European cooperation, whereas the resources generated by the cooperation which takes place exclusively within the single country (that is generated without any European interdependence) remain untouched by the common redistributive policy. Indeed, the national surpluses are to be redistributed according to the domestic redistributive schemes ${ }^{23}$.

As far as the second issue is concerned, I assert how a redistribution of the European surplus according to the European difference principle might be obtained implementing Fiscal Union at European level. As anticipated in the Introduction, in the present context Fiscal Union is to be meant merely as a system which can pool together into a common budget the resources generated by the European economic cooperation. To comply with the European difference principle a common European budget, reflecting the European surplus, becomes essential. Otherwise, without Fiscal Union, which pools the resources together, the European difference principle remains an elegant normative and theoretical outcome with no concrete perspectives.

It is not then an aim of the present paper to enter the debate concerning the practical (technical or political) implementation of European Fiscal Union. Nevertheless it is legitimate to promote some general considerations. In particular, there are two possible ways to interpret European Fiscal Union in the light of the European difference principle. On the one hand it is possible to think about a system which constantly collects and transfers the European surplus in order to maximize the expectations of the European worst-off. On the other hand it is also imaginable a sort of mechanism of insurance (Bénassy-Quéré et al. 2016 and Thirion 2017) which pools together the resources and which acts against systematic risks. In the latter perspective the European surplus might be collected in order to protect the weakest European parties in case of specific unfavourable conditions $^{24}$, or the budget might get into action when a set of European subjects goes below a certain minimum threshold.

About the way to implement concretely Fiscal Union at European level, Rawls himself provides some hints in $\S 43$ (Rawls 1999, pp. 242-251) when he describes the distributive branch. He states how one element of the "distribution branch is a scheme of taxation to raise the revenues",

considerations are due. First of all it is not so immediate to think about the rationale of redistributing across Europe resources generated by the social and economic cooperation which takes place exclusively within the boundaries of the single member states. Second, Morgan's (2008) example is not the situation designed in this paper through the European difference principle. Indeed, in the present analysis the redistribution can be claimed only according to the specific level of cooperation: within-country (domestic) redistributive rule on those resources generated by national cooperation and between-countries (European) difference principle for that surplus generated thorough European cooperation. Said otherwise, there is no constrain to redistribute only once at one single level, like stated by Freeman (2006, p. 63). Redistribution can take place twice or more times, for any level of cooperation and where a basic structure is available. Thus, national and European redistributive schemes are perfectly compatible.

23 In this perspective the following consideration becomes then false: "[t]he difference principle can apply only once to structure economic and property institutions, either globally or domestically. It cannot apply to both." (Freeman 2006, p. 63).

24 Rawls himself, between the background institutions for distributive justice, mentions a "stabilization branch" (Rawls 1999, p. 244). 
and which "make[s] the transfer payments necessary to satisfy the difference principle" (Rawls 1999, p. 246). Thus, a system of taxation at European level should be considered an essential part of European Fiscal Union in a Rawlsian perspective. Rawls then goes even further suggesting some specific taxes which might be adopted to generate the resources required for the redistribution (insurance mechanism) according to the difference principle: inheritance and gift taxes; proportional expenditure tax, that is tax on consumption; a proportional tax on annual consumption; an income tax is considered as well. It is even possible to speculate about a tax on those activities which make business across national borders (but within the Union), and so on and so forth.

Clearly ideas deserve a further deepening, since it is also necessary to consider that an improper tax scheme might generate frictions which nullify the benefits of the common market for some countries. However, those specific considerations are considered beyond the research question of the paper.

\section{Final remarks and conclusions}

The main conclusions of the analysis concerning the European Union in the perspective of the Rawlsian social contract theory can be summarized as follows: the current constitutional elements which characterize the European Union imply a precise redistributive scheme embodied in the European difference principle. A corollary that follows that conclusion concerns European Fiscal Union, which represents a possible way to implement such a redistributive scheme.

In reaching these conclusions, we have to take into account the difficulties to interpret Rawls' thought regarding the European Union, as he hardly ever lingered on the topic. However, we can be confident in the formulation of the European difference principle for two reasons. On the one hand we have to understand the fact that the European Union experienced by Rawls was very different from the today's Union. Although John Rawls was probably right in showing some eurosceptic traits in imagining a European Union based only on mere (socially empty) economic evaluations, the current Union is constituted by specific institutional elements which allow us to move beyond the mere functional economic structure. It is not longer possible to have a European market, many European supranational institutions, a European common currency but not a European system of welfare redistribution: such an institutional asymmetry unavoidably creates unjustified inequalities because of a "redistributive bias on national policy choices" (Scharpf 1998, p. 6).

On the other hand we should consider that Rawls himself left the hypothesis of a difference principle at European level open. He clearly states how there is "room for various forms of cooperative associations and federations among peoples" (Rawls 2000, p. 36), making explicit then the following hypothesis: "what does the Law of Peoples say about the following situation? Suppose that two or more of the liberal democratic societies of Europe, say Belgium and the Netherlands, or these two together with France and Germany, decide they want to join and form a single society, or a single federal union [...] A voter [...] might vote for the difference principle (the most egalitarian liberal conception)" (Rawls 2000, p. 43, note 53).

To conclude, the normative analysis provided throughout the paper applies Rawls' theory of domestic justice to the European Union. The European Union concretely holds those elements, the scheme of mutually advantageous cooperation and the parallel basic structure thanks to which we can conceive a European difference principle that requires to maximize the expectations of the European least advantaged. The concrete implementation of similar social welfare function requires 
to pool together those resources which are generated by means of the cooperation taking place at European level: this goal might be achieved by means of European Fiscal Union. In this way the Rawlsian redistributive scheme and Fiscal Union at European level can contribute to reduce the institutional gap between the European economic integration and the European social integration. 


\section{References}

Andreozzi, L., \& Tamborini, R. (2017). Why is Europe engaged in an inter-dependence war, and how can it be stopped?.

Avram S., Levy H., \& Sutherland H. (2014), Income Redistribution in the European Union, IZA Journal of European Labor Studies, 3(1), 22.

Badinger H. (2005), Growth Effects of Economic Integration: Evidence From the EU Member States. Review of World Economics, 141(1), 50-78.

Badinger H., \& Breuss F. (2011), 14 The Quantitative Effects of European Post-War Economic Integration, in Jovanović (ed.), International Handbook on the Economics of Integration: Factor Mobility, Agriculture, Environment and Quantitative Studies, Volume 3, (pp. 285-315), Edward Elgar, Cheltenham.

Beckfield J. (2006). European integration and income inequality, American Sociological Review, 71(6), 964-985.

Barcelos P. \& Queiroz R. (2008), Which Values for the European Union? Europe Between Principles of Domestic, published on http://www.ifilnova.pt and available at: http://ifilnova.pt/file/uploads/f795ccc5d80742c7fa8c53a5b64ac7d1.pdf.

Beitz C. R. (1999), Political Theory and International Relations, with afterward, Princeton University Press.

Bénassy-Quéré A., Ragot X., \& Wolff G. (2016), Which Fiscal Union for the Euro Area?, Brugel Policy Contribution, 5, 1-17.

Blake M. (2001), Distributive Justice, State Coercion, and Autonomy, Philosophy \& Public Affairs, 30(3), 257-296.

Blake M. (2012), Global Distributive Justice: Why Political Philosophy Needs Political Science, Annual review of political science, 15, 121-136.

Blake M. (2013), Justice and Foreign Policy, Oxford University Press.

Blake M. (2016), Agency, Coercion, and Global Justice: A Reply to My Critics, Law and Philosophy, 35(3), 313-335.

Blankart C. B. (2007), The European Union: Confederation, Federation or Association of Compound States?, Constitutional Political Economy, 18(2), 99-106.

Buchanan J. M. (1996), Europe as Social Reality, Constitutional political economy, 7(4), 253-256.

Campos N. F., Coricelli F. \& Moretti L. (2014), Economic Growth and Political Integration: Estimating the Benefits from Membership in the European Union Using the Synthetic Counterfactuals Method, Institute for the Study of Labor.

Chamon M. (2016), EU Agencies: Legal and Political Limits to the Transformation of the EU Administration, Oxford University Press.

Crespo Cuaresma J., Ritzberger-Grünwald D. \& Silgoner M. A. (2008), Growth, Convergence and EU Membership, Applied Economics, 40(5), 643-656.

Dluhosch B. (1997), Convergence of Income Distributions: Another Measurement Problem, Constitutional Political Economy, 8(4), 337-352. 
Dunaiski M. (2013), Principles of Distributive Justice Within the EU, written by a student as a part of his degree, published on http://www.e-ir.info/ and available at: http://www.eir.info/2013/04/05/principles-of-distributive-justice-within-the-eu/

Ferrera M. (2009), The JCMS Annual Lecture: National Welfare States and European Integration: In Search of a 'Virtuous Nesting', JCMS: Journal of Common Market Studies, 47(2), 219-233.

Ferrera M. (2014), Social Europe and its Components in the Midst of the Crisis: A Conclusion, West European Politics, 37(4), 825-843.

Freeman S. (2006), The Law of Peoples, Social Cooperation, Human Rights, and Distributive Justice, Social Philosophy and Policy, 23(01), 29-68.

Fredriksen, K. B. (2012). Income inequality in the European Union, OECD Economic Department Working Papers, No. 952.

Fuest C., \& Peichl A. (2012, April), European Fiscal Union: What Is It? Does It Work? And Are There Really'No Alternatives'?, In CESifo Forum (Vol. 13, No. 1, p. 3). Institut für Wirtschaftsforschung (Ifo).

Immervoll H., Levy H., Lietz C., Mantovani D., O’Donoghue C., Sutherland H., \& Verbist, G. (2006), Household Incomes and Redistribution in the European Union: Quantifying the Equalizing Properties of Taxes and Benefits, in The Distributional Effects of Government Spending and Taxation (pp. 135-165), Palgrave Macmillan UK.

Kamminga R. M. (2014), Rawls and the European Union, PHILICA.COM, Article number 425

Kölling M. (2015), How Much Solidarity Is in the EU Budget?, Perspectives on Federalism, 7(3), 77-97.

König J. \& Ohr R. (2012), The European Union - A Heterogeneous Community? Implications of an Index Measuring European Integration, Universität Göttingen, mimeo.

Kuper A. (2000), Rawlsian Global Justice: Beyond the Law of Peoples to a Aosmopolitan Law of Persons, Political theory, 28(5), 640-674.

Maduro M. P. (2000), Europe's Social Self:'The Sickness Unto Death', in Shaw J. (ed), Social Law and Policy in an Evolving European Union (pp. 325-349), Hart Publishing, Oxford.

Martin R. (2006), Rawls on International Distributive Economic Justice: Taking a Closer Look, in Martin R. \& Reidy D. (ed.), Rawls's Law of Peoples: A Realistic Utopia? (pp. 226-242), Oxford, Blackwell.

Martin R. (2015), Rawls on International Economic Justice in The Law of Peoples, Journal of Business Ethics, 127(4), 743-759.

Martinsen D. S. (2013), Welfare States and Social Europe, in U. Neergaard, E. Szyszczak, J. W. van de Gronden, \& M. Krajewski (ed.), Social Services of General Interest in the EU (pp. 53-73), chapter 3, The Hague: TMC Asser Press..

Martinsen D. S., \& Vollaard H. (2014), Implementing Social Europe in Times of Crises: Reestablished Boundaries of Welfare?, West European Politics, 37(4), 677-692.

Mathieu E. (2016), Regulatory Delegation in the European Union: Networks, Committees and Agencies, Springer. 
Morgan G. (2008), John Rawls: Eurosceptic? European Integration as a Realistic Utopia, available at: https://papers.ssrn.com/sol3/papers.cfm?abstract_id=1113223

Musgrave R. A. and Musgrave P. B. (1989), Public Finance in Theory and Practice, McGraw-Hill Internationa Edition.

Nagel T. (2005), The Problem of Global Justice, Philosophy \& public affairs, 33(2), 113-147.

Peterson J., \& Shackleton M. (2012), The Institutions of the European Union, Oxford University Press.

Pogge T. W. M. (1988), Rawls and Global Justice, Canadian Journal of Philosophy, 18(2), 227-256.

Rawls J. (1977), The Basic Structure as Subject, American Philosophical Quarterly, 14(2), 159-165.

Rawls J. (1999), A Theory of Justice, Revised Edition, Harvard University Press.

Rawls J. (2001), The Law of Peoples: with, the Idea of Public Reason Revisited, Harvard University Press.

Rawls J. \& Van Parijs P. (2003), Three Letters on The Law of Peoples and the European Union. Autour de Rawls, 7-20.

Sangiovanni A. (2013), Solidarity in the European Union, Oxford Journal of Legal Studies, 33(2), 213-241.

Sangiovanni A. (2016), Is Coercion a Ground of Distributive Justice?, Law and Philosophy, 35(3), 271-290.

Streit M. E., \& Mussler, W. (1995), The Economic Constitution of the European Community: From 'Rome' to 'Maastricht', European Law Journal, 1(1), 5-30.

Scharpf F. W. (1998), Interdependence and Democratic Legitimation, working paper, Max Planck Institute for the Study of Societies, Cologne.

Scharpf F. W. (2002), The European Social Model, JCMS: Journal of Common Market Studies, 40(4), 645-670.

Smith A. (1994), An inquiry into the nature and causes of the wealth of nations. Edited by Edwin Cannan. The Modern Library. New York.

Thirion G. (2017), European Fiscal Union: Economic Rationale and Design Challenges, CEPS Working Document No. 2017-01/January 2017, Archive of European Integration.

Vandenbroucke F. I. G. (2013), A European Social Union: Why We Need it, What it Means, Rivista Italiana di Politiche Pubbliche, 2, 221-247.

Valentini L. (2011), Coercion and (Global) Justice, American Political Science Review, 105(01), 205-220.

Van Parijs P. (2012), No Eurozone Without Euro-dividend, Unpublished Manuscript. http://www.fondationpaulricoeur.fr/uploads/medias/articles_pr/no-eurozone-withouteurodividend.pdf [entered 07/03/2017].

Van Parijs P. (2012) International Distributive Justice, in Goodin R. E., Pettit P., \& Pogge T. W. (ed.), A Companion to Contemporary Political Philosophy (Vol. 2, pp. 638-652), John Wiley \& Sons.

Vaubel R. (1996), The Constitutional Future of the European Union, Constitutional Political Economy, 7(4), 317-324. 
Vaubel R. (1997), The Constitutional Reform of the European Union, European Economic Review, 41(3), 443-450.

Viehoff J. (2016), Maximum Convergence on a Just Minimum: A Pluralist Justification for European Social Policy, European Journal of Political Theory, 0 (0), 1-24. 